\title{
THE LIFE AND DOCTRINE OF BUDDHA AND
}

\section{THE HOLY LANGUAGE OF BUDDHISM.}

\section{PUBLICATIONS OF TRÜBNER \& Co.,}

8 AND 60, PATERNOSTER ROW, LONDON.

In one volume, 8vo., pp. clxxii. and 206, cloth. 12s. 6 d.

BUDDHAGHOSHA'S PARABLES.

Translated from the Burmese, by Capt. H. T. Rogrrs, R.E. With an Introduction, containing Buddha's "Dhammapadam, or The Path of Virtue." Translated from the Pali, by F. Max MüllzR, M.A., LL.D.

\section{LECTURE ON BUDDHIST NIHILISM.}

By F. MAX MürLeR, M.A.; Professor of Comparative Philology in the University of Oxford; Member of the French Institute, ete. Delivered before the General Meeting of the Association of German Philologists, at Kiel, 28th Sept., 1869. (Translated from the German.) 18.

With a Folio Atlas of 20 Plates, and 20 Tables of Native Print in the Text, Royal 8vo., pp. xxiv. and 404. $\$ 228$.

BUDDHISM IN TIBET ;

Illustrated by Literary Documents and Objects of Religious Worship. With an Account of the Buddhist Systems preceding it in India. By Emin SchusarnTwert.

4to., pp. iv. and 32 , sewed. $2 \varepsilon .6 d$.

BUDDHA AND HIS DOCTRINES.

A Biographical Essay. By Oтto Kistnke.

8vo., pp. xi. and 538, v., sewed. $18 s$.

THE LIFE OR LEGEND OF GAUDAMA,

The Buddha of the Burmese, with Annotations. The Ways to Neibban, and Notice on the Phongyies, or Burmese Monks. By the Right Reverend P. BigandeT, Bishop of Ramatha, Vicar Apostolic of Ava and Pegu.

Crown 8vo., pp. lxxiii. and 210 , cloth, ornamental. 10s. 6 d.

TRAVELS OF FAH-HIAN AND SUNG-YUN,

Buddhist Pilgrims from CHINA to INDIA (400 A.D. and 518 A.D.). Translated from the Chinese, by Samure Bear, B.A., Trinity Coll. Cambridge; a Chaplain in H.M.'s Fleet; Member of the Royal Asiatic Society; and Author of a Translation of the "Pratimôksha" and the "Amithâba Sutra," from the Chinese.

In the press, in one volume, $8 \mathrm{ro}$.

HANDBOOK for the STUDENT of CHINESE BUDDHISM. By the Rev. E. J. Errex, of the London Missionary Society.

In preparation, in one volume, crown 8vo.,

A HISTORICAL ACCOUNT OF BUDDHISM IN CHINA.

From Original Chinese Sources.

By S. Bear, B.A., Trinity Jollege, Cambridge; a Chaplain in H.M.'s Fleet, \&c.

In preparation, in one volume, 8 vo.,

A DICTIONARY OF THE PÁLI LANGUAGE,

By Robert C. Childers.

Now ready, in 8vo., pp. 32 , stitched. $1 s, 6 d$.

KHUDDAKA PATHA,

A Pali Text, with a Translation and Notes. By B. C. Crunders, late of the Ceylon Civil Service. 


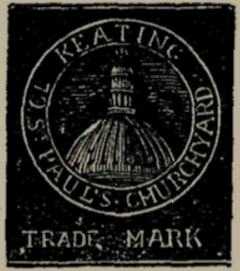

KEATING'S COUGH LOZENGES.

This UNIVERSAL REMEDY now stands the first in public favour and confidence; this result has been acquired by the test of fifty years' experience. These Lozenges may be found on Sale in every British Colony, and throughout India and China they have been highly esteemed wherever introduced. For COUGHS, ASTHMA, and all Affections of the THROAT and CHEST they are the most agreeable and efficacious remedy. They do not contain opium or any other deleterious drug, and may, therefore, be taken with perfect safety by the most delicate constitution.

\section{RECENT TESTIMONIAL.}

“A A ugust 23, 1868.

"Dran Sin,-Having tried your Cough Lozenges in India I have much pleasure in testifying to their beneficial effects in cases of Incipient Consumption, Asthma, and Brorchial Affections, so good a medicine ought to be known to be appreciated. I have prescribed it largely, with the best results.

"To Mr. Thomas Keating." "Apothecary H.M. Indian Medical Service."

Prepared and Sold in Boxes, Tins, and Bottles, by KEATING, Chemist, 79, ST. PAUL'S CHURCHY ‘D, LONDON, E.C. Sold Retail by all Druggists, \&c.

\section{Keating's Children's Worm Tablets.}

A PURELY VEGETABLE SWEETMEAT, both in appearance and taste, furnishing a most agreeable method of administering a well-known remedy for INTESTINAL or THREAD WORMS.

It is a perfectly safe and mild preparation, and is especially adapted for Adults and Children, being as harmless in its action as it is prompt and certain in its effects; and may be taken with impunity by the most delicate constitution,

Prepared and Sold in Tins and Bottles by THOMAS KEATING, Chemist, \&c., 79, ST. PAUL'S CHURCHYARD, LONDON, E.C., and Ketail by all Druggists and Patent Mledicine Vendors.

\section{FURNISH YOUR HOUSE WITII TIIE BEST ARTICLES

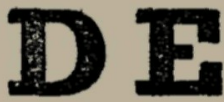 \\ $\mathbf{A T}$

$$
\text { ESTABLISHED A? } 1700 .
$$

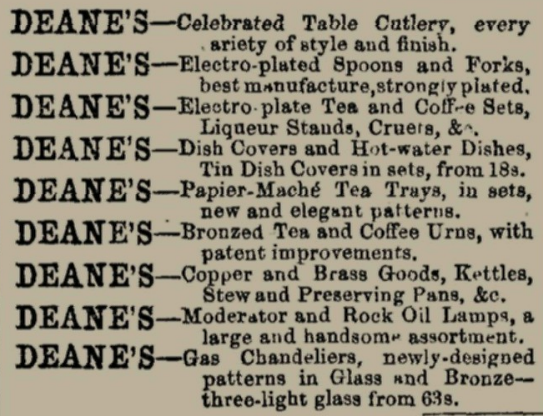

New Illustrated Catalogue with Priced Furnishing Lists Gratis and Post-free.
DEANE'S-Domestio Baths for every purpose, Bath-Rooms fltted complete. DEANE'S-Fenders and Fire-irons, in sll Bedding of superior quality.

DEANE'S-Register Stoves, improved LondonDEANE'S-Cornices and Cornico Poles, DEANE'S-Tin and Japanned Goods, IronWare and Calinary Utensils. DEANE'S-Turnery, Brashes, Msts, \&c., well made, strong, and servicesble.

DEANE'S-Horticultural Tools, Lawn Mowers, Garden Rollers, Wire Work, \&c. DEANE'S-Earness, Saddles, \& Horse Clothing. manufactured on the premises, and of the best material. DEANE'S-Bedsteads in Iron and Brass, with

A Discount of 5 per cent for Cash Payments of $£ 2$ and upwards

\section{DEANE \& CO, \{́k KNe wLLLian sT., $\}$ LONDON BRIDGE,}

